\title{
Nzinga Mbandi: From Story to Myth
}

\author{
Orquídea Moreira Ribeiro \\ CITCEM \\ UTAD, Portugal \\ oribeiro@utad.pt
}

\author{
Fernando Moreira \\ CITCEM \\ UTAD, Portugal \\ fmoreira@utad.pt
}

\author{
Susana Pimenta \\ CITCEM \\ UTAD, Portugal \\ spimenta@utad.pt
}

\section{ABSTRACT}

The figure of Queen Nzinga Mbandi continues to be appreciated in fictional and/or historical narratives as a myth of postcolonial Angolan identity, allowing a continuous approach as to what concerns the modes of cultural representation. In this article, the works of Manuel Pedro Pacavira, Nzinga Mbandi (1975), Pepetela, A gloriosa família: o tempo dos flamengos (1997) and José Eduardo Agualusa, A Rainha Ginga e de como os africanos inventaram o mundo (2014) will be analyzed, as these authors, in different moments of the recent Angolan history, look at this emblematic figure, drawing on historical information produced by Cavazzi, Cadornega or Jean Louis Castilhon, among others. The works now in analysis reiterate the mythical figure of resistance to the European invaders, which was Nzinga Mbandi, or a strong orientation towards the nationalist exaltation supported by it, an evident strategy which, by the rescue of figures and cultural practices, is defined as a means to affirm negritude.

\section{KEYWORDS}

Nzinga; Memory; Identity; Pepetela; Pacavira; Agualusa.

\section{1 | INTRODUCTION}

Angolan national heroine, with a statue symbolically erected in the center of the Angolan capital Luanda, Nzinga Mbandi [1] is also a name celebrated in the streets of other cities and towns of Angola. Central character of books, paintings and prominent in various stories, she is also a prominent figure in festive events that surpassed the African continent, being established in Brazilian lands where Africanity imposed itself through slavery.

In fact, what is known of Nzinga Mbandi comes mainly from the works of António Cavazzi, an Italian Capuchin priest and Nzinga's last confessor (Descrição Histórica dos Três Reinos do Congo, Matamba e Angola, Lisbon, 1965, with illustrations by Italian painters who had never been to Angola), of António Gaeta or António Romano, also an Italian Capuchin and also her confessor for years, ( $L a$ maravigliosa Conversione allá Santa Fede di Cristo della Regina Ginga e del Regno di Matamba nell'a Africa Meridionale, 1669) and of António de Oliveira de Cadornega, Portuguese military officer, (História Geral das Guerras Angolanas 1680-81), works produced by foreign men and in a particular context (and despite the inclusion of oral testimonies), that lead to, even today, enormous doubts and favor controversy.

As far as cultural representations are concerned, there is no doubt that Nzinga Mbandi has boosted a significant fantasy (see the illustrations accompanying Cavazzi's work), more recently enriched by some works that see her as or make her 
a protagonist of Angolan and African culture, regardless of historical truth [2].

\section{2 | NZINGA: THE FATE OF BEING QUEEN}

Being born with the umbilical cord wrapped around her neck (Heywood, 2017, p. 57) was interpreted by the soothsayers of the tribe as a negative sign, of bad omen, as Cavazzi reveals, supported in oral tradition; it was surely the mark of a different fate, of resistance and of survival. Nzinga descended from a line of strong kings - father and grandfather - who "had controlled a vast territory that covered a large portion of modern-day northern Angola, garnering respect from and instilling fear in their enemies and followers alike during the majority of their reigns" (Heywood, 2017, p. 56).

According to different narratives and reports, Nzinga Mbandi was her father Ngola Kiluanje's favourite child, for being intelligent and sagacious. It should be noted that Cavazzi, more than Cadornega and Gaeta, gives an image of Njinga that, as Alberto Oliveira Pinto wrote, leads to her "enselvajamento", her portrayal as a savage (Pinto, 2014, s/p), by endowing her with warlike, diabolic, anthropophagic or lewd characteristics. This positioning of Cavazzi, although it is evident that the main purpose of his "biography" of Njinga was to emphasize what he considers to be her miraculous conversion, has an obvious explanation, according to Linda Heywood and John Thornton:

However, whatever his deep feelings, Cavazzi remains essentially Anti-African, and his general contempt, even toward the Christian natives, strongly suggests that he regarded blacks as inferior, at least in virtue, to many peoples of the world. (2013, p. 3).

In spite of this, the Capuchin priest provides a fundamental indication for the understanding of Njinga and of her future as queen and resistant:

The king, her father, ordered her to be educated with great care and according to her status, and because he loved her more than any other child, because he recognized in her an extraordinary spirit and wit, he often blessed her during the ceremonies of the sect. (Cavazzi, 1965, p. 59).

As her father's favorite child, and before becoming queen after her brother's death, Nzinga already played a prominent role in the Ndungo kingdom and her appointment as a representative to the negotiations with the Portuguese based in Luanda are proof of this: she presented herself for the meeting with the Portuguese governor João Correia de Sousa leading an embassy with plenipotentiary powers (she was the bearer of the king's word), with pomp and circumstance, as narrated by Cavazzi: "full of precious gems, bizarrely adorned with feathers of various colors, majestic in size and surrounded by a large group of maidens and court officials" (Cavazzi, 1965, p. 63).

Nzinga was to star in two episodes worthy of registration during this meeting, according to Cavazzi and Cadornega, that revealed her political cunning: i) being there no chair reserved for her in the room, she sat on top of a female slave and then left the woman there, "For it was not proper for the ambassador of a great king to use the same chair twice" (Cavazzi, 1965 , p. 65); ii) and her baptism, sponsored by the Portuguese governor - "D. Ana de Sousa was born." Baptism, at the time and in the context that it occurred, was a habitual requirement which implied submission on the part of the defeated chief to the colonizer.

Cavazzi, who characterizes the yet princess as "full of spirit and dissimulation" (1965, p. 63), describes Njinga's action in these negotiations:

She was greatly admired for the liveliness of her attitude and the readiness of her intelligence, qualities that were not conceived in a woman. (...) She amazed, surprised, convinced all the council and the magistrates with such a natural disposition that they remained without words for a long time (Cavazzi, 1965, p. 64).

There is, therefore, an astute, defiant, intelligent, pragmatic, courteous, argumentative, lively and leading Nzinga; she will become queen in circumstances commented further on in this text and, according to Cavazzi, she "seemed to have been born only for war. Always at the head of many groups of 'jagas', she ran through the provinces dragging desolation everywhere like an impetuous chain" (Cavazzi, 1965, p. 83). She would die in 1663, at the age of eighty, after intense battles with the Portuguese, which, as she confessed to Father Gaeta, were responsible for the extreme actions she carried out (Cavazzi, 1965, p. 4); moreover, Gaeta, 
unlike Cavazzi, sees the second and definitive conversion of Nzinga, in 1654, to Christianity, as a "miracle happening to a fundamentally intelligent, spiritual, charming and pragmatic woman" (Heywood \& Thornton, 2013, p. 4). It will be based on these two axioms that the future representations of the black queen, her mythological status, her symbolic figure of blackness and negritude and of African nationalism and patriotism of resistance will be built on.

\section{3 | HISTORICAL AND CULTURAL REPRESENTA- TIONS OF NZINGA}

Nzinga Mbandi and her resilience to the European colonizing fury that was invested (and blessed) by the mantle of Catholic evangelization, would become, in Europe's Enlightenment, and thanks to the texts of Cavazzi and Gaeta, a Romanesque heroine, despite, as Oliveira Pinto (2014, p. 13) correctly observed, never having been enslaved and being a woman.

Jean-Louis Castilhon allowed himself to be seduced by the black queen and made her the protagonist of his book Zingha, reine de l'Angola. Histoire Africaine en deux parties, published in 1769; this French author, also a collaborator of the Grande Encyclopédie (1751-1772) of Diderot and Dalembert, closely focuses on the information provided by Cavazzi, although in the preface to Zingha, reine de I'Angola. he explains that his work is inspired by the information provided by Gaeta; therefore, Oliveira Pinto is emphatic: "Njinga is turned into a savage by Castilhon by the same processes used by the Italian Capuchin" (Pinto, 2014, p. 13). Even so, Patrick Graille sees in the romanesque composition of Castilhon "an enlightened Zingha, who could have reigned loyally and peacefully (...) an unconventional heroine" (Graille, 2016, p. 49); Patrick Graille expresses his opinion regarding the way the French writers of yesterday and today see Queen Nzinga as the myth she would become:

To qualify Njinga, an adjective returns to the pen of French, ancient, and contemporary writers: 'extraordinary' (...) The queen remains a complex, inaccessible, mysterious figure who demands plural non-Manichaean readings (Graille, 2016, p. 54).

In fact, Castilhon's work, using as an example this savage, cruel, brutal, and lewd Zhinga that he retrieved from Cavazzi's text, presents the queen as an exceptional heroine, an extraordinary woman who lives with her court in a kind of paradise, thus fighting the classical opposition between barbarians and civilized. Her "bad behavior" is justified by herself in response to the Capuchin friars who wanted to convert her and, thus, clean her of guilt:

I would never have been cruel, wicked, if the Portuguese had respected my crown and the rights of my birth, and had not usurped my states and defeated my throne. Against the natural generosity of my feelings, against the softness of my character, I became a monster of ferocity. Which is! Are they not more fierce than I, those who by anger and usurpation have infuriated my wrath and pierced my soul with the fire of vengeance? (Castilhon, 1769, $p$. 102).

If there is a character / personality whose secular fortune symbolically includes a cultural representation of the "bad savage" that the early centuries of Portuguese African colonial domination would call a "cafraria," this figure is Queen Nzinga Mbandi, in life and in times gone by. The "discourse of demerit" mentioned by Inocência Mata (2012, p. 23) justified an exercise of power that had its culmination in the commercialization of slaves. In Portugal, at the end of the eighteenth century, there were references to the vileness present in any connection to the blackness that Nzinga symbolized. See, for example, how this "stain" entered into the discourse of Viradeira [3], under the pretext of a supposed genealogical connection to Africa of the minister of King José [4], Sebastião José de Carvalho e Melo, Marquis of Pomba [5], fallen in disgrace after the death of the king:

Return, return marquis the dark forest Mansion of the fifth grandfather, the archdeacon That of Mother Marta, for her black cuddle In black he made your fortune fall (...)

Friends, what's up? Does it smell like 'catinga'? For it is he who ruled by our sorrows A fifth grandson of Queen Ginga (Brito, 1990, p. 361).[6]

Manuel Maria Barbosa du Bocage's [7] verminous pen also gave voice to this form of insult rooted in society in two sonnets in which Bocage aimed at the Brazilian mestizo poet Domingos Caldas Barbosa [8], in the context of a literary quarrel: 
Presides the grandson of Queen Ginga

To the vile, sycophantic, insane

Dirty little lad brings samples of goat stew

In unequal cups the 'pinga' [alcohol] runs out

(Bocage 1991: 11)

\section{Disgusting offspring of Queen Ginga (...) \\ Roasted gecko, stupid 'resinga' \\ (...)}

But your verses stink of 'catinga':

It is because, oh Caldas, being only

A kaffir, a joke, a noodle, a fool, an excrement

You want to stick your nose in people's backside.

(Bocage 1991: 16). [9]

Oliveira Pinto correctly exposes the cultural (and social) meaning of this phrasing:

the Portuguese of the eighteenth century already persist in repudiating the idea that they might descend from Africans, by means of an attitude of social and identity exclusion of their own countrymen on whom such suspicions might fall. And the image of Queen Njinga is reduced to the condition of allegory of this feeling of racism (Pinto, 2014, p. 16).

\section{4 | NZINGA, SYMBOL OF NATIONALIST RESIS- TANCE}

Nzinga Mbandi, the black queen who called herself king, would become an African symbol of resistance to European colonial domination and is, without a doubt, the most important political figure in Angola, a fact amplified by the exemplary role she has been portrayed in during the past half a century in novels, narratives and other texts.

\section{1 | NZINGA MBANDI, BY MANUEL PEDRO PACAVIRA}

In Manuel Pedro Pacavira's novel, Nzinga Mbandi, the protagonist is "the central figure of a 'grand narrative', proper to the logic of nationalist ideology, in a discourse that contradicts the history of the colonizer (the one that appears in the História geral das guerras africanas of António de Oliveira de Cadornega) and his 'discourse of demeriting the Africans'" (Mata, 2012, p. 23)," (Mata, 2016, p. 81); for Mata, with Pacavira's text the queen becomes part of the "founding national history" as the author "takes from documental historical 'reality' enough elements to discuss her in the Angolan culture", according to a questioning perspective of the historical formation (Mata 2016: 87-89). In fact, the essence of Pacavira's novel lies in a simple but grandiose act, as Linda Heywood e John Thornton correctly mentioned, "The entire text of Pacavira is an operation of transformation of Queen Njinga into a figure of anticolonial resistance" (Heywood \& Thornton, 2013, p. 19), opinion shared by Abreu Paxe, who explains it in the following terms: "In fact, the novel Nzinga Mbandi is a metaphor for the marks of what has become the symbol of resistance to colonization" (Paxe 2012: 20). The way Manuel Pedro Pacavira processes this transformation and builds a mythical symbol of resistance is worth analyzing. After producing a long history of the relations of the Kongo and Ngola peoples with the Portuguese since the arrival of Diogo Cão in 1482 at the mouth of the river Zaire, Pacavira introduces the character of Nzinga at a time when African resistance is at a crucial point, the war is at its peak, the fire burning, as described by the author:

The war never stops. The foreigners will not triumph. The fire is on. More lit up than in the times of Ngola Kiluanje Kia Samba. With a woman's name running from mouth to mouth among the people, among the enemies. A woman's name. To demand respect only by listening to Nzinga Mbandi (Pacavira 1975, p.116).

Nzinga is, therefore, invested with a natural power of the people and of the enemies ... and she is a woman! A leader who already was before actually becoming a leader; the king is still Ngola Mbandi, her brother, but it is Nzinga that the people and the adversaries respect. It is of her that there is talk about, always her, the "beloved granddaughter of Ngola Ndambi", of her that at 40 years of age portrays an image of vitality, of determination that the mother country offered her; was "cheerful, jovial, in the vigor of life, without white hair, with nothing. And without anything to bend her" (Pacavira, 1975, p. 118). It was with this image and this fame that, acting as king, Nzinga will present herself in Luanda for negotiations with the Portuguese in 1622; she is a woman who carries with her the rumor "of walking where only the bird-chicks could walk through before. And sleep where only the animals could sleep" (Pacavira 1975: 118). She is Africa and its magic.

In Luanda a new Nzinga appears, the negotiator, the strategist, who pushes her determination as leader to 
the limit, strategically converting to Christianity, receiving the name of Ana de Sousa. It was as if she was legitimated as leader by the enemy, the Portuguese governor João Correia de Sousa. Ngola Mbandi, her brother and king, who had killed her son and sterilized her, did not realize what had happened, "for a daughter of her father could not have a name of 'matumbos' [word designating the Portuguese]. It would be better for her to die." (Pacavira 1975: 119). Without knowing it, he was right. He would die "instantly. Without being or feeling sick. (...) Poison in the food?" (Pacavira, 1975, p. 122), while the discussion regarding Nzinga's "betrayal" lasted, with the future queen-king facing the charges firmly. The mystery of his death remains unresolved: had it been the intention of the gods since it was not a spell? This explanation of Pacavira for the passage of power between Ngola Mbandi and Nzinga Mbandi is described by Mata as "a delicate and subtle solution" (Mata 2016: 88), because the power struggle between the two siblings "has been a difficult crossroads to express in the narrative" (Mata, 2016, p. 88) for Angolan historiography.

Pacavira was subtle, mainly because his speech gives evident signs of the inevitability of the arrival to power of Nzinga. Revenge and murder among her people did not match the construction of a myth, a symbol of the colonial resistance that he wants to build. The son of Ngola Mbandi still calls himself the new Ngola, but "True Ngola was she, Kalunga, Nzinga Mbandi, and nobody else" (Pacavira 1975: 126), because the elderly and elders of the quilambas and sanzalas wanted it so. They wanted the "elder" (Nzinga) as king, "the one that had the full rights of Kijinga. And she deserved it (...). Just her." (Pacavira, 1975, p. 125).

The power speech of enthroned Nzinga is a display of patriotism and resistance, a pure and natural harangue of leadership. To the immense crowd that heard it, "to that whole world the granddaughter of Ngola Ndambi swore that the war was not going to stop" (Pacavira, 1975, p. 126). She quoted her father Ngola Kiluanje, the soldier-king, the one who had declared total war against the ambitious Portuguese:

The triumph of the enemy, the ruin of the Motherland, the loss of its independence. The disappearance of its History and ways and customs. Their children to serve as slave (...). No one should want to be a slave. Rather die holding a bow and spear than becoming a slave (Pacavira, 1975, p. 126).

This refers to a seventeenth-century speech by Queen Nzinga, but it is also a twentieth-century resistance speech of the liberation struggle that would lead to independence. This is a speech by the real Ngola people, worthy heirs of this "True Ngola, Nzinga Mbandi, and nobody else" (Pacavira, 1975, p. 126).

Nzinga Mbandi is the queen of the people: "Various days the Mother-Queen remained home to confer with 'Kilambas' and 'Sobas' (...) she met with the elders in council, met with the people, listened to the people (...) she does not live in palaces" (Pacavira, 1975 , p. 132). She is always on the front lines of battle, in victories and defeats (Pacavira 1975, p. 147148), years and years without "divert[ing] the paths trodden by his eldest, he Ngola Mbandi. The paths his father will highly recommend he follows. That death holding a bow and spear was preferable, yes sir, to life, even of a thousand years, serving. The life of a slave" (Pacavira, 1975, p. 149). All this, writes Pacavira, was as "our contemporary elders would say: to impose the National War of Liberation" (Pacavira, 1975, p. 149), that is, the mythification of the struggle for independence through the Ngolas and, in particular, the figure of Nzinga Mbandi. Therefore, as Inocência Mata concludes,

'Nzinga Mbandi' is a work that thematizes the history of Angola through identifiable figures in time and space (...) aiming at a profile of national identity from the territorial mapping drawn on the cement of ethnic solidarity and political consciousness of the territory of Ngolas (Mata, 2016, p. 24).

The book by Pacavira is, as it turned out, an entire nationalist and identity construction of an inaugural past projected into the present, also inaugural, and the figure of Nzinga Mbandi is built (and mythicized from a 180-degree rotation: from the "Portuguese" image that the historical texts of Cavazzi and Cadornega combine, that is, a bloodthirsty, cruel and demonic queen) to serve this purpose ... Not by chance the dedication of the work is "To FAPLA Heroic Fighters of Freedom", a dedication that fulfills, according to Mata, "the ideological-cultural ideology for the construction of a society that seeks an African identity through the rescue and valorization of 
elements excluded from 'the national culture"' (Mata 2012: 26-27).

\section{2 | A GLORIOSA FAMÍLIA BY PEPETELA}

Unlike the novel by Pacavira, A Gloriosa Familia by Pepetela, published more than twenty years later in 1997, does not have as an active character Nzinga Mbandi, nor is it even a novel about her; however, the time of the narrative is marked by this historical figure, present through an "ostensible absence" (Mata, 2012, p. 27). In A Gloriosa Familia the construction of Jinga is more a deconstruction of a mute Ngola slave who commands the narration and who, living in the midst of the enemy, releases information that runs counter to a negative image that the Portuguese express (Pepetela, 1997, p. 19; 167; 224). He is also a Ngola patriot, though a slave and exiled, or for that very reason, who, moreover, is self-credited as the most capable of exposing historical truth. Those who tell the story are not the Flemings (the narrative occurs between 1641 and 1648, time of the Dutch occupation of Luanda and Benguela, and the subtitle of the novel is O tempo dos Flamengos, are not the Portuguese, but a slave from the court of Jinga, who was raised by one of her sisters, known as Mocambo or Dona Barbara. Baltazar Van Dum, Flemish of origin, but Catholic and "Portuguese" by adoption, is the owner of the slave, but Jinga is his king; the slave lives between Luanda and the Van Dum plantation, but the Ngola kingdom is his homeland, and he considers Jinga as politically skilled, "amazingly clever at making and breaking the silences at the [perfect] moment for greater effect" (Pepetela, 1997, p. 168); he is a worthy patriot, a manager of a screaming silence, for throughout the text he says he is writing the truth that others translate as manipulated. He refers to that at the beginning of the book:

Jinga made war against the Portuguese as she still does. The Portuguese say she is cannibal, a viper that cannot be trusted, but I have another version. By the way, I still have not seen an enemy disregarded as a demon (Pepetela, 1997, p.23, our underlining).

Through the slave's voice, Jinga's reason for the wars is explained: "my king, who is Queen Ginga, always said, was I very small, but already grasping some things, whites are very hungry for gold and silver" (Pepetela, 1997, p. 369). Jinga was king, and "she demanded to be treated as king and not queen"
(Pepetela, 1997, p. 253) and in this capacity, unlike other women, she only sits in armchairs or on the backs of slaves (Pepetela, 1997, p. 86). In addition to the mute slave, Cadornega also makes Jinga present in the narrative plot and, despite the her diabolization by the Portuguese, the lieutenant, who fought against her, expresses his admiration for the black queen: "foreigners were very impressed by her power. She can always insinuate the idea that she is the strongest and achieves everything. We have to pay homage to her, she is diabolically intelligent and skilled" (Pepetela, 1997, p. 253). The comment of the slave to this statement by Cadornega is indeed elucidative as to the historical truth and the future mythical projection of the character: "I liked to hear lieutenant Cadornega, a man of letters and of thought, recognizing the merit of my king, being the most hated enemy. Hated are those who have some value" (Pepetela, 1997, p. 253-4).

The aura of Jinga's power is also recognized by the representative of the king of Congo and his occasional ally, D. Agostinho de Corte-Real: "Ginga does not complain, she kicks up a fuss, demands. It is also true that she has always been the one that faced the Portuguese" (Pepetela, 1997, p. 325), and the slave concludes: "The king of Kongo's representative had to acknowledge Jinga's determination, which contributed to increase my vanity" (Pepetela, 1997, p. 325). As it turns out, Jinga "circulates" in A Gloriosa Família by what others narrate, which amplifies her presence: she already belongs to the domain of the storytelling, of the folktale, hovering over the reality of others.

\section{3 | A RAINHA GINGA BY JOSÉ EDUARDO AGUALUSA}

José Eduardo Agualusa writes one of his last historical novels around the mythical figure known as Nzinga (writes Ginga). In A Rainha Ginga. E de como os africanos inventaram o mundo (2014), Agualusa builds and deconstructs the woman who invented "a new world", dedicating the edition "to all African women, who, every day, are inventing the world" (Agualusa, 2014a, s/p). José Eduardo Agualusa presents, between history and fiction, the life of an African queen who has become iconic and representative in Angolan culture, particularly in the black feminist movements, for the force with which she fought against the various forms of oppression in a world of men. It is thus a historical novel, with facts 
"stolen from reality" (Agualusa, 2014, p. 280), and for which the author has used works by authors such as António de Oliveira Cadornega, Giovanni Cavazzi da Monteccucolo or Andrew Battel complemented with adaptations of texts by historian Luís Mott, in the case of examples regarding the punishment of slaves (Agualusa, 2014, p. 280).

The story of Ginga is written in an African perspective, from the African court, but narrated by Father Francisco José da Santa Cruz, from Pernambuco, "resorting to a South/South dialogue in which the North was no more than the subjugating instance that led to the contact between the worlds of the different occupied 'Suis"' (Wieser, 2017, p. 46). Santa Cruz is a mestizo, the son of a Brazilian Indian and a mulatto, and shares, in part, subalternity with Africans, and he also seems to be "a cultural hybrid" (Wieser, 2017, p. 47), representative of the miscegenation of Brazil, also a product of Portuguese colonization. However, this does not mean that he does not identify with the colonizers. Agualusa describes him as a "translator of languages", but essentially a "translator of worlds", with a "plausible" profile, justifying that "it would be artificial to put the action in the mouth of Queen Ginga", considering that as "one of the errors of the books published about her: [therefore] they do not pass the truth" (Agualusa, 2014a, s/p).

In the voice of the Pernambucan priest, Agualusa presents a positive portrait of the "queen-king" "queen Ginga, or better king Ginga, because that's how she demanded to be called" (Agualusa, 2014, p. 55), allowing the reader to regard her as a mythical heroine of the struggle against Portuguese colonization in her performance and "individual eccentricity" (Wieser 2017: 49) of non-man and nonwoman, who governs according to her "laws, intelligence and understanding" (Agualusa, 2014, p. $35)$, as it is denoted in the episode in which Ginga goes to the palace of the governor João Correia de Sousa. The Portuguese governor received her "sitting in a high chair, almost a throne" and had reserved "a cushion, draped in gold, on a silky carpet", to which Ginga renounces, giving "orders to one of her slaves, a young woman with a graceful figure, named Henda, to kneel on the carpet and, to the great astonishment of all those present, sat on the back of the unfortunate woman" (Agualusa, 2014, p. 35), an attitude that "marked the tone of the meeting, or the 'maca', in the words of the 'ambundos'” (Agualusa, 2014, p. 36). Ginga thus emerges as a determined and defiant woman, secure and with the gift of oratory, to the point that Francisco José da Santa Cruz, when he heard her "speak with such brilliance and justice" (Agualusa, 2014, p. 36), he set himself several times on the side of the African barricade. Rodrigo de Araújo, a Portuguese merchant, has a different opinion; so much fluency "is something of the supernatural (...) the intelligence, when it manifests itself in a woman, and more so in a woman of black color, so unheard of, should be the inspiration of the evil one and, therefore, matter of the competence of the Holy Office" (Agualusa, 2014, p. 37-38). Astutely, with the intention of fortifying the agreement with the Portuguese, Ginga wanted to receive the waters of baptism; "The decision was not of a spiritual nature, but of a political one" (Agualusa, 2014, p. 39), becoming according to Christian law, Dona Ana de Sousa.

In an interview, José Eduardo Agualusa mentions that the main objective of his work is "to show that the Africans were not a passive part in this whole process of construction of Angola, Africa, Brazil, even Portugal" (Agualusa, 2014a , s/p). Hence, it is important to inquire about the representation of Queen Nzinga Mbandi in fiction and/or historical narratives until the construction of this figure as a myth of the postcolonial Angolan identity, with each political power using the figure of Nzinga in his own image. As José Eduardo Agualusa recalls, in an interview with Visão magazine: "there was [on the one hand] some colonial literature, that is, fiction produced by the Portuguese, using the myth of the queen in favor of the myth of the construction of the empire"; on the other hand, in the post-independence period, "a book with the opposite perspective, hypernationalist, transforming Queen Ginga into an icon of Angolan nationalism - which is also absurd" was edited, referring to the queen as not "Angolan" and as someone who did not fight "for the idea of Angola" (Agualusa, 2014 a s/p), considering her rather an icon of the African woman. Moses Malumbo, in the text "Ginga no alvor da diplomacia e do nacionalismo angolano" (2012), exalts the nationalist fervor that the figure of the "queen-king" represents in Angolan society a model of struggle in defense of the territory and its development, in the struggle against obscurantism and, as an example of life, in the struggle for the emancipation of women (Malumbo, 2012, p. 83-85). 


\section{5 | CONCLUSION}

Everything in the life of Nzinga Mbandi competes towards the formation of the myth: her first "biographers" compared her to the great female figures of history, but being black, African, relentless warrior, converted Christian and cannibal, and finally reconverted into laity of holiness, one could almost say that her legendary fortune was a kind of preannounced reality. Undoubtedly, the works of Pacavira, Pepetela or Agualusa are two different approaches in the way of facing the Angolan past, one more political, others more identity and culture related; each, in its own way, builds a mythical hero figure around Nzinga Mbandi, the basis of both is similar, namely, a process of inversion of the image that for centuries crystallized: a savage, treacherous, lewd, cruel, cannibal, murderous Nzinga, and, moreover, since times then justified her actions, a woman. After all, who contributed most to her mythification, even if involuntarily, but the Portuguese, her greatest detractors? Nzinga Mbandi, D. Ana de Sousa, was the "Black Queen", a recognition that, beyond the inherent negativity of the nickname, does not fail to consecrate her call for leadership in defense of her people, her territories and the neighboring peoples who she tried to congregate/conquer. It is not by chance that Cornelio Caley, former deputy minister of Culture of Angola, affirmed in a congress dedicated to her: "Around Queen Nzinga, the Ngola Kings and many others, developed the dynamics that defined the territory that is now known as Angola" (Caley, 2012, p. 8). She was an "outstanding example of female governance" (UNESCO, 2014, p. 7) in times of pure male power [10].

\section{ENDNOTES}

[1] Historical figure, Angolan queen (1583-1663). The Queen is referred to as Njinga, Nginga, Zingha, Ginga, Jinga, Nzinga - the different forms of writing her name - according to the different authors and languages. The version used in the title of this article, Nzinga Mbandi was inspired by the title of Manuel Pedro Pacavira's narrative.

[2] See Njinga Mbandi - Queen of Ndongo and Matamba was published in the UNESCO Series on Women in African History in 2014. It includes a pedagogical unit and a comic strip. The UNESCO Series "aims to highlight a selection of key women figures in African history" and "highlight their legacy."
[3] Set of satirical compositions written against the Marquis of Pombal after his exit from power.

[4] (1714-1777); reigned 1750-1777.

[5] (1699-1782); Secretary of the State of Internal Affairs of the Kingdom from 1750 to 1777.

[6] "Torna, torna marquês à mata escura / Solar do quinto avô, o arcediago / Que da Mãe Marta, por seu negro afago / Em preto fez cair tua ventura / (...) / Amigos, e que tal? Cheira a catinga? / Pois é quem governou por nossas penas / Um quinto neto da rainha Ginga" (Brito, 1990, p. 361).

[7] Portuguese poet (1765-1805).

[8] (1739-1800)

[9] "Preside o neto da Rainha Ginga / À corja vil, aduladora, insana / Traz sujo moço amostras de chanfana / Em copos desiguais se esgota a pinga (Bocage 1991: 11)

Nojenta prole da rainha Ginga / (...) / Osga torrada, estúpido resinga / (...) / Mas teus versos tresandam a catinga: / É porque sendo, oh Caldas, tão somente / Um cafre, um gozo, um néscio, um parvo, um trampa / Queres meter o nariz em cu de gente." (Bocage 1991: 16).

[10] Free translation of quotations in Portuguese and French.

\section{REFERENCES}

Agualusa, José Eduardo (2014). A Rainga Ginga. E de como os africanos inventaram o mundo. Lisboa: Quetzal.

Agualusa, José Eduardo (2014a). Pela primeira vez, sinto que posso dizer que sou escritor. Revista Visão. Disponível em http://visao.sapo.pt.

Bocage, Manuel Maria Barbosa du (1991). Poesias Eróticas, Burlescas e Satíricas. Lisboa: ERL.

Brito, António Ferreira de (1990). Cantigas de Escárnio e mal-dizer do Marquês de Pombal ou a crónica rimada da Viradeira. Porto: Associação de Jornalistas e Homens de Letras.

Caley, Cornélio (2012). Nota de abertura. In: A Rainha Nzinga Mbandi - História, Memória e Mito. Lisboa: Edições Colibri, 7-9. 
Castilhon, Jean-Louis (1769). Zingha, Reine d'Angola. Histoire Africaine en Deux Parties. Paris: A. Bouillon.

Cavazzi de Montecúccolo, João António (1965 [1687]). Descrição Histórica dos Três Reinos do Congo, Matamba e Angola, 2 Vols.. Lisboa: Junta de Investigações do Ultramar.

Cavazzi, J. António (2013). Njinga, Rainha de Angola. Edição de Linda Heywood e John Thornton. Lisboa: Escolar Editora.

Gioia, Francesco Maria (1669). Antonio de Gaeta La maravigliosa conversione alla santa fede di Cristo della Regina Singa e del suo regno di Matamba nell'Africa Meridionale. Napoli: Giacinto Passaro.

Graille, Patrick (2016). La Reine Njinga d'Angola en France d'hier à aujourd'hui. Angola e as Angolanas Memória, sociedade e cultura. São Paulo: Editora Intermeios, 33-55.

Heywood, Linda M. (2017). Njinga of Angola: Africa's warrior queen. Cambridge, Massachusetts: Harvard University Press.

Heywood, Linda \& Thornton, John (2013). Prefácio. Njinga, Rainha de Angola. Lisboa: Escolar Editora, 119.

Malumbo, Moisés (2012). Ginga no alvor da diplomacia e nacionalismo angolano. Inocência Mata (Org.), A Rainha Nzinga Mbandi. História, Memória e Mito. Lisboa: Ediçoes Colibri, 77-87.

Mata, Inocência (2012). Representações da Rainha Nzinga Mbandi na Literatura Angolana. A Rainha Nzinga Mbandi - História, Memória e Mito. Lisboa: Edições Colibri, 23-46.
Mata, Inocência (2016). Njinga a Mbandi: o desafio da memória. Pantoja, Selma; Bergamo, Edvaldo J. \& Silva, Ana Cláudia (Org.). Angola e as Angolanas Memória, sociedade e cultura. São Paulo: Editora Intermeios. 75-83.

Pacavira, Manuel Pedro (1979). Nzinga Mbandi. Lisboa: Edições 70.

Paxe, Abreu (2012). Da semente à floresta - uma metáfora para a leitura do romance histórico de Manuel Pedro Pacavira. Inocência Mata (Org.). A Rainha Nzinga Mbandi, História, Memória e Mito. Lisboa: Edições Colibri, 17-21.

Pepetela (1997): A Gloriosa Família. Lisboa: D. Quixote.

Pinto, Alberto Oliveira (2014). Representações Culturais da Rainha Njinga Mbandi (c. 1582-1663) no discurso colonial e no discurso colonialista africano. In: Estudos Imagética. Rio de Janeiro: UERJ/CHFLUL. Internet. http://repositorio.ul.pt/bitstream/10451/12027/1/Repr esenta\%C3\%A7\%C3\%B5es\%20Culturais\%20da\%2 ORainha\%20Njinga\%20Mbandi\%20com\%20imagen s.pdf

UNESCO (2014). Njinga Mbandi - Queen of Ndongo and Matamba. UNESCO Series on Women in African History. Paris. Editorial and artistic direction: Edouard Joubeaud.

Wieser, Doris (2017): A Rainha Njinga no diálogo sulatlântico: género, raça e identidade. Iberoamericana, XVII，66, 31-53. Internet. https://journals.iai.spkberlin.de/index.php/iberoamericana/article/view/2409 
